\title{
Análise de Textos de Divulgação Científica sobre Genética Inseridos em Livros Didáticos de Biologia
}

\author{
Analysis of Texts of Scientific Dissemination on Genetics Inserted in \\ Biology textbooks
}

\author{
Bruna Sarpa Miceli ${ }^{a}$; Marcelo Borges Rocha ${ }^{a}$ \\ a Centro Federal de Educação Tecnológica Celso Suckow da Fonseca, Rio de Janeiro, Brasil - brunasm213@gmail.com, \\ rochamarcelo36@yahoo.com.br
}

\section{Palavras-chave: Divulgação científica. Genética. Livros didáticos. Reelaboração discursiva. Linguagem.}

\section{Keywords:}

Scientific dissemination. Genetic. Textbooks.

Discursive re-

elaboration. Language.
Resumo: Este artigo apresenta a relação da divulgação científica (DC) juntamente com a genética e os livros didáticos (LDs). Foi questionado que alterações ocorrem nos textos de DC quando estes são inseridos nos LDs de Biologia e que implicações essas alterações podem provocar no entendimento sobre ciência. O objetivo desta pesquisa é analisar as possíveis modificações realizadas no LD em relação às suas fontes originais. Uma coleção de LD de Biologia do Ensino Médio foi selecionada e sete textos foram analisados de acordo com as categorias de reelaboração discursiva, natureza da ciência, linguagem e grau de hibridez dos textos do LD. Os resultados indicaram que a exclusão foi o elemento mais frequente durante a reelaboração discursiva, apesar dos textos contribuírem para uma visão de natureza da ciência e apresentarem recursos linguísticos que facilitam a compreensão do leitor representando recursos importantes para serem utilizados no ensino.

Abstract: This article presents the relation of scientific dissemination (SD) with genetics and textbooks. It was questioned what changes occur in the SD texts when they are inserted in the Biology textbooks and what implications these changes can cause in students' understanding about science. The objective of this research is to analyze the possible modifications carried out in the textbooks in relation to their original sources. One collection of high school biology textbooks was selected and seven texts were analyzed according to the categories of discursive re-elaboration, nature of science, language and degree of hybridity of the texts of the textbooks. The results indicated that the exclusion was the most frequent element during discursive re-elaboration, although the texts contribute to a vision of the nature of science and present linguistic resources that facilitate the reader's understanding of important resources to be used in teaching. 


\section{Introdução}

As atividades de Divulgação Científica (DC) não são recentes na sociedade. De acordo com Silva (2006), ela se originou juntamente com a Ciência Moderna. Já no Brasil, a DC se intensificou com a vinda da Corte Portuguesa e a partir da criação da Imprensa Régia onde surgiram os primeiros jornais e periódicos. Atualmente, a DC consiste em um recurso capaz de veicular o conhecimento científico para o público em geral. Tal veiculação é realizada através dos meios de comunicação (como jornais, televisões, rádios, livros e internet) e de espaços não formais de ensino e que são divulgadores da ciência, como no caso dos museus (MOREIRA; MASSARANI, 2002; LOUREIRO, 2003; BUENO, 2010; SOUZA; ROCHA, 2015).

No que tange seus discursos, a DC é entendida como uma "atividade de reformulação" (ZAMBONI, 1997, p.74), pois a mesma passa por uma série de adaptações, desde o momento em que é produzida (por cientistas) apresentando-se em artigos científicos, até atingirem outras fontes do discurso, como as revistas de divulgação e os livros didáticos. Tais adaptações são conhecidas por diversos autores como 'reelaborações discursivas' (MARTINS et al., 2001; SOUZA; ROCHA, 2014; 2015; PASSERI et al., 2017) e serão utilizadas nesta pesquisa.

Targino (2007) defende que a DC é originada a partir da interseção entre um discurso científico e um discurso jornalístico. O primeiro utiliza-se de termos técnicos e possui uma linguagem formal e precisa, com caráter persuasivo. O mesmo pode ser encontrado em publicações acadêmicas. O segundo, por sua vez, é um discurso presente em jornais, revistas e noticiários e geralmente é adaptado do primeiro. Apresenta linguagem coloquial e é de caráter informativo, o que estabelece uma aproximação com o público leitor.

Em concordância com Martins et al., (2001), o discurso científico pode ser entendido como aquele que abrange diversas formações discursivas relacionadas à diferentes tipos de textos, como aqueles presentes nos artigos científicos, nos jornais e revistas e no livro didático. Entretanto, para entendê-los, é necessário compreender os aspectos particulares de cada texto, tal como o seu funcionamento, a maneira como são produzidos, as repercussões que causam no leitor e, principalmente, a forma como são realizadas as reelaborações discursivas de um texto para o outro, ou seja, desde o momento de sua produção (através dos artigos científicos) até a utilização deste conhecimento no âmbito escolar (através dos livros didáticos).

Neste sentido, os livros didáticos (LDs) assumem grande importância ao retratarem aspectos da DC em seus conteúdos, principalmente devido ao papel desempenhado pela escola em desenvolver o saber científico e a formação crítica de indivíduos. Desta forma, os textos de DC presentes no LD podem ser observados através de seções voltadas para a relação 
da ciência com temas atuais. Estas seções podem ser intituladas de diversas formas, como 'ciência e tecnologia', 'ciência e sociedade', 'saiba mais', entre outras.

A utilização destes textos oferece uma proximidade do público escolar com os elementos da ciência. Além disso, são capazes de proporcionar debates e discussões sobre diversos assuntos e ainda podem instigar a curiosidade do aluno e promover o desenvolvimento de aptidões como a leitura e a interpretação (MARTINS et al., 2001; PUIATI et al., 2007; FERREIRA; QUEIROZ, 2012; SOUZA; ROCHA, 2014).

\section{Genética e DC}

Os avanços da ciência, juntamente com a tecnologia, ficam cada vez mais evidentes na vida em sociedade. Eles passaram a ser vistos com otimismo e como sinônimo de bem estar, possibilitando uma série de benefícios para a população, como no caso da engenharia genética, dos avanços na indústria farmacêutica e das vacinas, garantindo que a expectativa de vida fosse maior. Um elemento de grande repercussão foi o mapeamento do genoma humano, proposto em 1980, que visava o sequeciamento das bases nitrogenadas do genoma humano. Isso permitiu o estudo detalhado dos genes que compõem um organismo, assim como a descoberta das causas de doenças hereditárias (TEMP; BARTHOLOMEI-SANTOS, 2014; TEIXEIRA; SILVA, 2017).

Outro exemplo marcante sobre esta abordagem foi em relação ao processo de clonagem da ovelha Dolly, em 1997. Segundo Nascimento e Martins (2005), após a repercussão deste noticiário, a genética (principalmente assuntos relacionados à biotecnologia e engenharia genética) passou a ser incorporada e discutida com mais freqüência nas mídias digitais, impressa e televisiva.

Ainda a respeito da relevância ao veicular os conhecimentos da ciência, de acordo com Nascimento e Martins (2005), os meios de comunicação contribuem para manter o cidadão atualizado e informado frente aos novos progressos do ramo da ciência e da tecnologia, principalmente os temas ligados à genética. Relacionando a genética com as propostas dos textos de DC, pode-se ainda incluir a possibilidade de esclarecer temas considerados abstratos ou de difícil compreensão, além de buscar despertar o interesse do aluno aproximando a temática a partir de acontecimentos ocorrentes no cotidiano destes jovens (MASCARENHAS, et al., 2016).

Em relação à DC, vale a pena lembrar que a importância desta ferramenta está pautada no fato de que a DC oferece a possibilidade de aproximar o conhecimento científico da sociedade. Desta forma, diz-se que além de desempenhar uma função informativa, ela é capaz de apresentar um papel educador na veiculação da ciência (ZAMBONI, 1997; BUENO, 2010). Tal finalidade educativa é apresentada por alguns autores (MARTINS et al., 2001; 
FERRARI et al., 2005) no que diz respeito ao progresso da leitura e da interpretação científica, além da promoção da cultura científica.

Com base na importância assumida pela genética no ensino de ciências e pelo seu destaque na atualidade, além do papel desempenhado pela DC em aproximar os saberes da ciência da população, questionamos que alterações ocorrem nos textos de DC quando estes são inseridos nos livros didáticos de Biologia e que implicações essas alterações, caso existam, podem provocar no entendimento sobre Ciência pelos estudantes.

Acredita-se que tais textos incorporados no LD servem como ferramentas auxiliares importantes no processo de ensino-aprendizagem dos jovens e que ainda sejam capazes de contemplar temas referentes à ciência, com o intuito de levar a informação para este público escolar. Sendo assim, esta pesquisa tem como objetivo analisar as possíveis alterações sofridas nos textos de DC ao serem inseridos nos LDs.

Justifica-se a escolha da genética como a temática de análise, uma vez que a mesma é considerada um ramo da ciência interdisciplinar, capaz de trazer à tona questões éticas, sociais, tecnológicas, políticas e econômicas incorporadas na aplicação do conhecimento científico e na possibilidade que esta temática oferece, de refletir sobre a relação presente entre a ciência, a tecnologia e a sociedade (BRASIL, 1998; 2000; MOURA et al., 2013; TEMP; BARTHOLOMEI-SANTOS, 2014).

Em relação aos LDs, os mesmos foram escolhidos como objeto de estudo pelo fato de constituírem-se como um importante recurso no ensino, capaz de direcionar o processo de ensino-aprendizagem e auxiliar na estruturação e organização do conteúdo curricular (XAVIER et al., 2006; FIOREZE; e DELIZOICOV, 2015; DIAS, et al., 2016).

\section{Metodologia}

$\mathrm{O}$ presente estudo baseia-se em uma pesquisa qualitativa, de caráter descritivo e documental (GIL, 2002; SÁ-SILVA et al., 2009), onde foi selecionada uma coleção de LD de Biologia pertencente ao Programa Nacional do Livro Didático (PNLD) de 2018 a qual é composta por três volumes, cada um destinado a uma série do Ensino Médio. A coleção em questão é a Biologia, cujos autores são César da Silva Júnior, Sezar Sasson e Nelson Caldini Júnior. Vale a pena lembrar que a escolha da mesma justifica-se pela sua aprovação neste último PNLD do Ensino Médio, além de sua aprovação no Guia do Livro Didático de 2018, o qual informa diversos aspectos destes materiais de forma crítica (BRASIL, 2017). 
Quadro 1: Coleção de livros didáticos de Biologia analisada.

\begin{tabular}{|l|l|l|l|l|}
\hline COLEÇÃO & AUTORES & VOLUME & EDITORA & EDIÇÃO \\
\hline Biologia & $\begin{array}{l}\text { César da Silva Júnior, } \\
\text { Sezar Sasson e Nelson } \\
\text { Caldini Júnior }\end{array}$ & Vol.1 & Saraiva & $12^{\mathrm{a}}$ ed, 2017 \\
\cline { 3 - 3 } & & Vol.2 & & \\
\cline { 2 - 3 } & & Vol.3 & & \\
\hline
\end{tabular}

Fonte: Os autores.

Após a seleção da coleção, buscou-se analisar os três volumes a fim de identificar textos que retratassem conteúdos referentes à temática de genética. Ressalta-se que durante a leitura e busca por tais textos, optou-se por restringir a análise para os textos cujas referências oferecidas eram de cunho jornalístico, sendo retiradas das mídias digitais (portais da internet como blogs e noticiários ou de instituições de pesquisa científica) e impressas (jornais e revistas). Desta forma, foi possível totalizar sete textos, os quais foram retirados de fontes variadas de consultas e que foram codificados de T1 à T7, como mostra o quadro 2.

Quadro 2: Textos retirados da coleção Biologia selecionados para análise.

\begin{tabular}{|c|c|c|c|c|}
\hline CÓDIGO & VOLUME & TÍTULO & $\begin{array}{l}\text { SEÇÃO } \\
\text { RETIRADA }\end{array}$ & FONTE \\
\hline $\mathrm{T} 1$ & V1 & Sem título & Leitura: deu na mídia & Site 'Veja' \\
\hline T2 & V1 & Sem título & $\begin{array}{l}\text { Diálogos: produção e } \\
\text { fruição de artes }\end{array}$ & Site 'G1' \\
\hline T3 & V3 & Rosalind Franklin & $\begin{array}{l}\text { Introdução do } \\
\text { capítulo }\end{array}$ & Folha de São Paulo \\
\hline T4 & V3 & $\begin{array}{l}\text { Uma esperança contra a } \\
\text { distrofia muscular }\end{array}$ & Leitura: deu na mídia & Revista USP \\
\hline T5 & V3 & $\begin{array}{l}\text { Transfusões sanguíneas: } \\
\text { um pequeno histórico }\end{array}$ & $\begin{array}{l}\text { Introdução do } \\
\text { capítulo }\end{array}$ & $\begin{array}{l}\text { Fundação Pró- } \\
\text { Sangue }\end{array}$ \\
\hline T6 & V3 & $\begin{array}{l}\text { Cientistas tentam } \\
\text { desenvolver } \\
\text { espermatozóides femininos }\end{array}$ & $\begin{array}{l}\text { Leitura: Biologia e } \\
\text { tecnologia }\end{array}$ & Site 'O globo' \\
\hline T7 & V3 & $\begin{array}{l}\text { A polêmica do arroz } \\
\text { dourado }\end{array}$ & Leitura: deu na mídia & Folha de São Paulo \\
\hline
\end{tabular}

Fonte: Os autores.

Os sete textos foram analisados de acordo com a metodologia proposta pela análise de conteúdo, de Laurence Bardin (BARDIN, 1977). Esta técnica utiliza-se da análise de mensagens presentes em diversas formas de comunicação inclusive de materiais como textos escritos, seja por meio de artigos produzidos em pesquisas, matérias presentes em jornais e outras fontes ou através de transcrições de entrevistas (CAREGNATO; MUTTI, 2006). Para a análise dos textos, quatro categorias foram elencadas:

Reelaboração discursiva: nesta pesquisa, buscou-se observar as alterações realizadas pelo texto pressente no LD em relação às suas fontes originais de acordo com os padrões estabelecidos por Gomes (1995): acréscimos, substituições, eliminações e reordenações de informações. A reelaboração discursiva representa uma forma de análise utilizada por diversos autores que desejam observar as modificações do discurso da DC (MARTINS et al., 2001; NASCIMENTO, 2005; SOUZA; ROCHA, 2014; PASSERI et al., 2017). 
Natureza da ciência: Pode ser entendida como "uma rica descrição da ciência, como esta trabalha, como os cientistas atuam enquanto grupo social e como a sociedade se comporta frente à atividade científica" (SOUZA, 2017, p.98). Em outras palavras, a natureza da ciência consiste em apresentar a ciência como fruto da produção científica, exemplificando seus métodos e contribuindo, assim, na construção da cidadania dos indivíduos de uma sociedade. Nesta categoria, buscamos identificar se os textos apresentavam uma visão mistificada e deturpada da ciência (como parte de um processo construído e já elaborado) ou se contribuíam para uma concepção realista de ciência (com debates, sem neutralidade).

Linguagem: Buscou-se analisar a presença de possíveis erros conceituais, termos explicativos, metáforas e analogias. A análise de tais recursos linguísticos também foram utilizadas por alguns autores durante suas pesquisas (MARTINS et al., 2001; GOLDBACH e EL-HANI, 2008; KEMPER et al., 2010; SOUZA e ROCHA, 2014, 2015; 2017).

Grau de hibridez dos textos presentes no LD: Tal definição é apresentada por Souza (2017), onde os textos presentes no LD são considerados como: (i) textos híbridos, (ii) textos semi-híbridos e (iii) textos editados.

\section{Resultados e discussão}

\section{Reelaboração discursiva}

A exclusão de informações pôde ser observada em diversos textos analisados (T1; T3; T4, T5; T6; T7). Notamos os acréscimos de informações em T2 e T7, e as substituições foram encontradas em T5. Já as reordenações não foram observadas.

Em T1, o autor do LD realizou duas exclusões que foram sinalizadas pelo uso das reticências (Quadro 3). Tais eliminações consistiram em dados de pesquisa, explicações sobre a doença em questão (autismo), assim como as falas de pesquisadores. Acredita-se que o texto didático tenha se preocupado em selecionar as informações e abordar apenas o que julgou ser necessário para o contexto do livro. 
Quadro 3: Eliminações (em itálico) de informações presente no texto 1.

\begin{tabular}{|c|c|}
\hline TEXTO ORIGINAL & TEXTO DIDÁTICO \\
\hline $\begin{array}{l}1^{\circ} \text { P: "Uma nova pesquisa mostrou como o defeito no } \\
\text { funcionamento de um único gene causa alterações cerebrais que } \\
\text { podem levar ao comportamento típico dos indivíduos } \\
\text { com autismo. O estudo, publicado na revista PLoS ONE, oferece } \\
\text { uma nova possibilidade de tratamento para a condição. } \\
2^{\circ} \mathrm{P} \text { : AUTISMO } \\
\text { Distúrbio que afeta a capacidade de comunicação e de estabelecer } \\
\text { relações sociais. O autista comporta-se de maneira compulsiva e } \\
\text { ritual. O distúrbio, que pode afetar o desenvolvimento normal da } \\
\text { inteligência, atinge cinco em cada } 10.000 \text { crianças e é de duas a } \\
\text { quatro vezes mais frequente no sexo masculino. } \\
8^{\circ} \text { P: Segundo os pesquisadores essa descoberta pode levar ao } \\
\text { desenvolvimento de novos tratamentos para o autismo. "A partir } \\
\text { do momento em que entendemos o mecanismo, isso abre caminho } \\
\text { para desenvolver novas drogas para tratar a condição", afirma } \\
\text { Cecilia Giulivi. }\end{array}$ & $\begin{array}{l}1^{\circ} \mathrm{P} \text { : "Uma nova pesquisa mostrou } \\
\text { como o defeito no funcionamento } \\
\text { de um único gene causa alterações } \\
\text { cerebrais que podem levar ao } \\
\text { comportamento típico dos } \\
\text { indivíduos com autismo. [...] } \\
7^{\circ} \text { P: Segundo os pesquisadores } \\
\text { essa descoberta pode levar ao } \\
\text { desenvolvimento de novos } \\
\text { tratamentos para o autismo. }[\ldots]\end{array}$ \\
\hline
\end{tabular}

Já T2, diferente de T1, não apresentou exclusões em relação à sua fonte original. Este texto apenas acrescentou um parágrafo antes de reproduzir o texto encontrado na referência de origem. Neste acréscimo, o autor do livro realizou uma breve introdução do assunto que será abordado, o qual era referente às ciências e às artes (quadro 4). Este elemento da reelaboração pode ser utilizado com o intuito de tornar a informação mais clara e organizada para o leitor (SOUZA; ROCHA, 2014).

Quadro 4: Acréscimo (em itálico) realizado pelo autor do LD.

\begin{tabular}{|c|c|}
\hline TEXTO ORIGINAL & TEXTO DIDÁTICO \\
\hline $\begin{array}{l}\text { 10P: "O quadro de Christian e Marla pode }+{ }^{\circ} \text { não ter a cara deles, mas é o retrato mais fiel } \\
\text { que os dois poderiam ter. A peça, que em } \\
\text { breve vai decorar a parede da sala do casal, } \\
\text { é a reprodução do DNA, o código genético } \\
\text { de cada um. "É uma arte personalizada para } \\
\text { gente, com a nossa informação. Ninguém } \\
\text { tem igual", diz Christian Malheiro } \\
\text { Dinesen." }\end{array}$ & $\begin{array}{l}\mathbf{1}^{\mathbf{0}} \mathbf{P}: \text { "Temas biológicos muitas vezes exerceram um } \\
\text { grande fascínio em artistas plásticos. A pesquisa que } \\
\text { vocês poderão realizar, neste momento, é bastante livre. } \\
\text { Trata-se de descobrir casos em que artistas utilizaram } \\
\text { moléculas biológicas, como proteínas ou DNA, como } \\
\text { fonte de inspiração para a produção de pinturas ou } \\
\text { esculturas. Veja o texto abaixo, que fornece um exemplo } \\
\text { destes. } \\
\mathbf{2}^{\mathbf{0}} \mathbf{P} \text { : "O quadro de Christian e Marla..." }\end{array}$ \\
\hline
\end{tabular}

O T3, que abordou a vida e o histórico de Rosalind Franklin realizou seis eliminações durante todo o texto, sendo apenas três sinalizadas pelas reticências. Tais eliminações eram referentes à vida de Rosalind (de momentos da sua vida profissional até o momento em que a pesquisadora foi diagnosticada com câncer no ovário), suas características, além de opiniões sobre a pesquisadora, conforme foi exemplificado no quadro 5. Não foram observados acréscimos, reordenações ou substituições de informação neste texto em relação à sua fonte original. 
Quadro 5: Eliminação não sinalizada referente a opinião de um pesquisador sobre Rosalind Franklin.

\begin{tabular}{|c|c|}
\hline ORIGINAL & \\
\hline $\begin{array}{l}\mathbf{1 0}^{\mathbf{0}} \text { P: “... Há quem diga que ela teve a intuição errada, ou que } \\
\text { não ousou o suficiente para chegar à estrutura atualmente } \\
\text { aceita. Watson, por exemplo, afirma que ela não soube } \\
\text { interpretar seus próprios dados. O historiador da ciência } \\
\text { Robert Olby defende que ela foi cuidadosa e evitou tirar } \\
\text { conclusões apressadas. Outros afirmam que ela chegou muito } \\
\text { mais perto do que se imagina da estrutura do DNA. O que se } \\
\text { sabe é que Franklin obteve imagens de DNA de excelente } \\
\text { qualidade em 1952, em especial a de número } 51 . \\
\mathbf{1 1}^{\mathbf{0}} \text { P: Enquanto Franklin finalizava seu trabalho no } \\
\text { King's...." }\end{array}$ & $\begin{array}{l}\text { intuição errad } \\
\text { suficiente pa } \\
\text { atualmente ace } \\
\text { ela chegou mu } \\
\text { imagina da est } \\
\text { sabe é que Fra } \\
\text { DNA de excel } \\
\text { em especial } \\
\mathbf{5}^{\circ} \mathbf{P} \text { : Enquant }\end{array}$ \\
\hline
\end{tabular}

No caso de T4, o texto original era extenso em comparação com o texto didático. Neste sentido, foi possível observar três exclusões sinalizadas pelas reticências durante todo o texto do LD. De acordo com o quadro 6, duas destas eliminações podem ser observadas. A primeira era referente à data de publicação da pesquisa que relaciona o gene Jagged 1 com a distrofia, já a segunda, acredita-se que a informação tenha sido retirada por representar-se de forma confusa, necessitando ser mais bem explorada e explicitada.

Quadro 6: Eliminações realizadas do texto original para o texto didático.

\begin{tabular}{|c|c|}
\hline TEX & $\mathbf{O}$ \\
\hline $\begin{array}{l}\mathbf{2}^{\mathbf{0}} \text { P: “... comparáveis às que carregamos. Além disso, pela } \\
\text { primeira vez, descobriu-se uma associação entre o } \\
\text { gene Jaggedl e a doença. A pesquisa foi publicada online neste } \\
\text { dia } 12 \text { de novembro pela revista científica Cell, e estará na } \\
\text { edição impressa do dia 19. A Cell é o periódico de maior índice } \\
\text { de impacto nas áreas de biologia molecular e bioquímica, de } \\
\text { acordo com a medição Thomson-Reuters" } \\
7^{\mathbf{0}} \mathbf{P} \text { : "São raríssimos os casos em meninas, porque o gene da } \\
\text { distrofina está no cromossomo X e elas precisariam herdar os } \\
\text { dois cromossomos com defeito. Isso é praticamente impossível, } \\
\text { já que homens com Duchenne não se tornam pais - por morte } \\
\text { precoce ou falta condições físicas. Outra possibilidade é haver } \\
\text { uma troca de genes entre o cromossomo X } e \text { outro } \\
\text { cromossomo, ainda no óvulo que deu origem à menina. } \\
\text { Situações assim já foram reportadas." } \\
\mathbf{8}^{\mathbf{0}} \text { P: "A distrofia de Duchenne ainda não tem cura e os } \\
\text { cuidados disponíveis são apenas paliativos, como fisioterapia e } \\
\text { remédios à base de corticoides." }\end{array}$ & 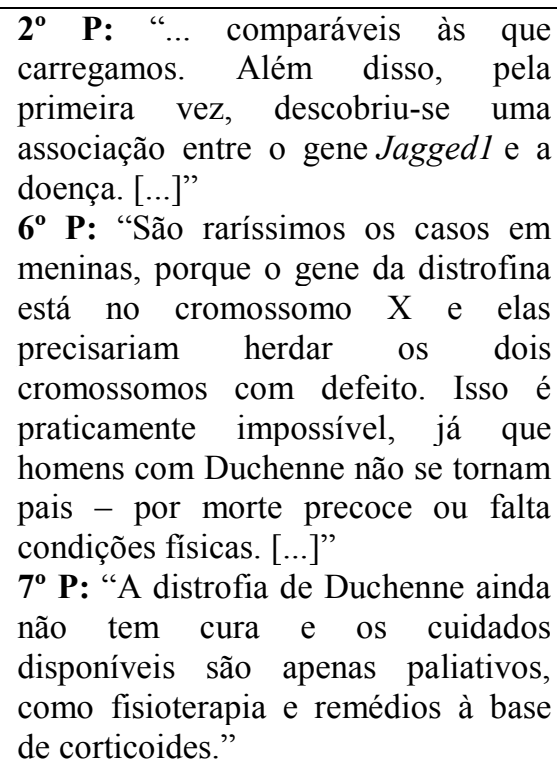 \\
\hline
\end{tabular}

O restante do texto original, que foi retirado da revista da USP, não foi aproveitado para o LD. O impacto desta retirada, portanto, deve-se à falta de informações de como o trabalho foi realizado em parceria com a Universidade de Harvard, os animais utilizados para este estudo da distrofia como o camundongo, peixes e em especial, o cão da raça Golden Retriever, além do detalhamento do processo do estudo do gene Jagged 1, que também foi eliminado do texto didático.

O texto 5 apresentou 13 exclusões no LD, sendo 12 sinalizadas pelas reticências e uma não. Algumas das exclusões eram referentes a conceitos e as demais consistiam em pequenas 
eliminações de fragmentos ou palavras que não alteraram o caráter/sentido do conteúdo. Além das exclusões, T5 apresentou uma correção através da substituição da palavra “coagula” por "aglutina", indicando que o sangue apenas se aglomera quando em contato com outro sangue de outro indivíduo (Quadro 7). Vale lembrar que as substituições também foram observadas por Souza e Rocha (2014), onde uma palavra era substituída por uma similar ou sinônima a ela, como no caso do trecho presente na referência original 'disponibilidade de alimentos' para 'quantidade de presas' no LD. Nascimento (2005) também notou substituição de informação no verbo 'trabalhar', onde no texto original era apresentado 'trabalham' no presente e no texto didático este mesmo verbo estava no passado: 'trabalhavam'. Acredita-se, desta forma, que as substituições visam tornar os textos mais claros para o leitor por meio de pequenas alterações de palavras ou letras.

Quadro 7: Substituição (em negrito) da palavra 'coagular' para 'aglutinar' no texto didático.

\begin{tabular}{|c|c|}
\hline TEXTO ORIGINAL & TEXTO DIDÁTICO \\
\hline $\begin{array}{l}\text { "Em 1900, final do Século 19, o imulologista } \\
\text { austríaco, Karl Landsteiner, observou que o soro } \\
\text { do sangue de uma pessoa muitas vezes coagula ao } \\
\text { ser misturado com o de outra, descobrindo o } \\
\text { primeiro e mais importante sistema de grupo } \\
\text { sangüíneo existente no organismo: o ABO." }\end{array}$ & $\begin{array}{l}6^{\circ} \mathrm{P} \text { : "Em 1900, final do Século } 19 \text {, o imulologista } \\
\text { austríaco, Karl Landsteiner, observou que o soro } \\
\text { do sangue de uma pessoa muitas vezes [..] } \\
\text { aglutina ao ser misturado com o de outra, } \\
\text { descobrindo o primeiro e mais importante sistema } \\
\text { de grupo sangüíneo existente no organismo: o } \\
\text { ABO.[...] }\end{array}$ \\
\hline
\end{tabular}

O sexto texto (T6) realizou três exclusões de informações. Estas eliminações podem ser observadas no texto a partir da presença de reticências. Em uma das eliminações, o autor do LD retirou um parágrafo do texto original como pode ser observado no quadro 8 . Uma possível explicação para a retirada desta informação está relacionada com o fato deste parágrafo retratar uma possibilidade para um relacionamento entre casais homossexuais. Deste modo, o autor também retirou uma questão que necessariamente precisa ser retratada e conversada no ambiente escolar.

Quadro 8: Exclusão de parágrafo para o texto original.

\begin{tabular}{|c|c|}
\hline TEXTO ORIGINAL & TEXTO DIDÁTICO \\
\hline $\begin{array}{l}\mathbf{2}^{\circ} \mathbf{P} \text { : "Se as experiências conseguirem atingir os seus objetivos } \\
\text { será possível, dizem os cientistas, desenvolver óvulos graças à } \\
\text { manipulação de células masculinas e espermatozóide a partir de } \\
\text { células } \\
\mathbf{3}^{\mathbf{0}} \mathbf{P} \text { : O avanço científico poderia permitir que casais de } \\
\text { homossexuais possam ter sua descendência sem precisar de } \\
\text { gametas do sexo oposto, ainda que o útero de uma mulher } \\
\text { continue a ser necessário para o desenvolvimento normal da } \\
\text { gravidez. } \\
\mathbf{4}^{\mathbf{0}} \mathbf{P} \text { : Neste momento..." }\end{array}$ & $\begin{array}{l}\mathbf{2}^{\mathbf{0}} \mathbf{P} \text { : "Se as experiências } \\
\text { conseguirem atingir os seus } \\
\text { objetivos será possível, dizem os } \\
\text { cientistas, desenvolver óvulos } \\
\text { graças à manipulação de células } \\
\text { masculinas e espermatozóide a } \\
\text { partir de células femininas. } \\
{[\ldots]} \\
\mathbf{3}^{\mathbf{0}} \mathbf{P} \text { : Neste momento..." }\end{array}$ \\
\hline
\end{tabular}

O texto sete (T7), por outro lado, apresentou sete exclusões sinalizadas pelas reticências e apenas um acréscimo. $\mathrm{O}$ acréscimo observado foi referente à palavra "comenta" para evidenciar a fala de um pesquisador (Quadro 9). 
Quadro 9: Exclusões (itálico) de trechos e acréscimo (negrito) de palavra observado em T7.

\section{TEXTO ORIGINAL}

140 P: "Paira por aí muita desinformação a respeito dos OGMs que é tomada como fato pelas pessoas", disse Michael Purugganan, professor de genômica e biologia e pró-reitor de ciências da Universidade de Nova York. "Os genes que eles inseriram para fazer a vitamina não são nenhum material manufaturado esquisito, mas sim genes encontrados também em abóboras, cenouras e melões", escreveu ele em uma cartilha publicada pelo GMA News Online, veículo noticioso filipino. "Muitas das críticas aos OGMs no mundo ocidental padecem da falta de compreensão sobre como a situação é realmente difícil nos países em desenvolvimento."

\begin{abstract}
TEXTO DIDÁTICO
$\mathbf{7}^{\mathbf{0}} \mathbf{P}$ : “[...] Michael Purugganan, professor de genômica e biologia e pró-reitor de ciências da Universidade de Nova York [comenta] "Os genes que eles inseriram para fazer a vitamina não são nenhum material manufaturado esquisito, mas sim genes encontrados também em abóboras, cenouras e melões", escreveu ele em uma cartilha publicada pelo GMA News Online, veículo noticioso filipino.
\end{abstract}

As exclusões englobaram frases e parágrafos inteiros e eram referentes a questões sociais (preocupação da população com a utilização de transgênico), tecnológicas (uso da tecnologia neste processo) e econômicas (empresas e fundações que apoiam os testes com o arroz dourado, como a Fundação Bill e Melinda Gates). Além disso, foram retiradas falas de cientistas, dados publicados em revistas como a Scientific American e de artigos científicos (Quadro 10).

Quadro 10: Exclusões de dados realizadas em T7.

\begin{tabular}{|c|c|}
\hline TEXTO ORIGINAL & TEXTO DIDÁTICO \\
\hline 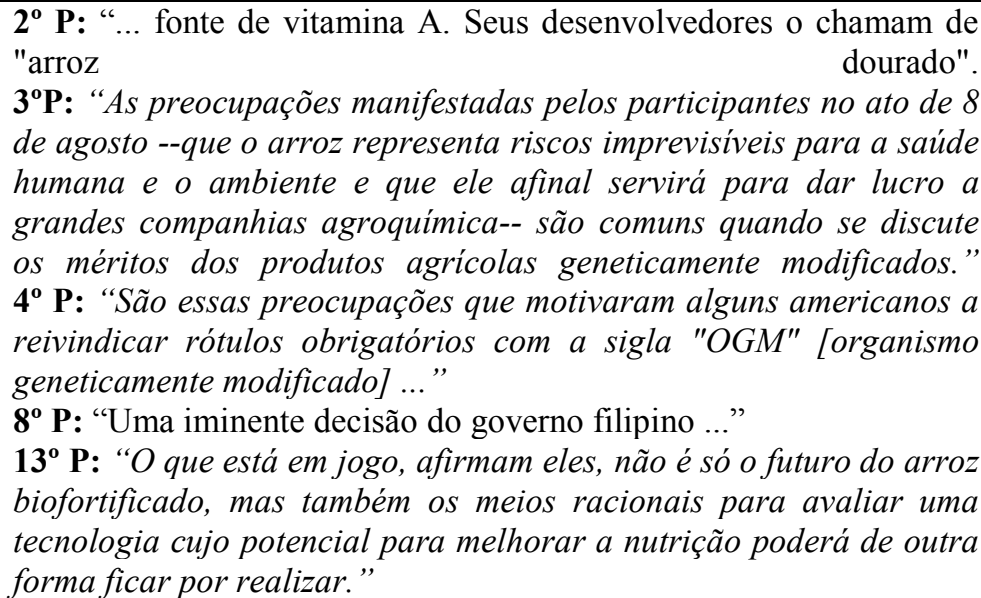 & $\begin{array}{l}\mathbf{2}^{\circ} \text { P: “... fonte de vitamina A. } \\
\text { Seus desenvolvedores o chamam } \\
\text { de "arroz dourado". } \\
{[\ldots]} \\
\mathbf{3}^{\mathbf{0}} \text { P: "Uma iminente decisão do } \\
\text { governo filipino sobre permitir } \\
\text { ou não o cultivo do arroz } \\
\text { dourado fora dos quatro campos } \\
\text { de teste remanescentes confere } \\
\text { uma nova dimensão ao debate } \\
\text { sobre os méritos dessa } \\
\text { tecnologia." }\end{array}$ \\
\hline
\end{tabular}

Em concordância com Passeri et al., (2017), os dados eliminados durante os textos analisados constituíam-se falas de pesquisadores e de fragmentos que poderiam ser discutidos, tornando o texto mais rico. Outros trabalhos como Souza e Rocha (2014) também observaram eliminações de pequenas expressões entre os textos, assim como eliminações que fizeram com que o texto didático reduzisse significativamente de tamanho.

\section{Natureza da Ciência}

Nesta categoria, encontramos textos que apresentavam uma visão distorcida da ciência ou que não corroboravam para a compreensão de como a ciência vem sendo construída (T4); textos que contribuíam parcialmente para esta visão, ora apresentando dados relevantes sobre a pesquisa e ora, retirando-os (T1; T3 e T7) e textos que colaboraram para um olhar de ciência 
não neutra, imersa em debates e controvérsias e que apresenta informações sobre o processo de construção do conhecimento científico (T2; T5 e T6).

Em determinados momentos de T1, este apresentou dados sobre a pesquisa, citando uma fala da pesquisadora/autora do estudo (Cecilia Giulivi). Contudo, o autor do LD também realizou duas exclusões que eram referentes à pesquisa. Tais exclusões puderam ser observadas durante a análise da categoria de reelaboração discursiva (Quadro 3). A exclusão de falas de pesquisadores, assim como de dados referentes à pesquisa também foram observados na pesquisa de Martins et al., (2001) durante a análise da natureza da ciência de um texto referente ao Cerrado e por outros artigos da literatura (SOUZA e ROCHA, 2014; PASSERI et al., 2017).

Por outro lado, T2 manteve dados referentes à pesquisa, que podem ser observados nas frases “A invenção surgiu no Laboratório Nacional de Células Tronco Embrionárias da UFRJ. Ideia de um pesquisador que soube enxergar toda a beleza do código genético.”; "Uma parte do dinheiro com a venda dos quadros vai ajudar a manter o laboratório, um dos mais importantes centros de pesquisa sobre células tronco no país.”. Em outro momento, o texto didático também apresentou uma fala do pesquisador e coordenador do Laboratório de células-tronco, Steven Rehen: “... Aproximar o grande público da ciência, fazendo com que as pessoas tenham na parede das suas casas uma obra de arte que na verdade é ciência pura, Stevens Rehen, coordenador do laboratório de células-tronco / UFRJ”. Vale lembrar que a fala deste pesquisador também retratou a necessidade de promover a DC para a população e de aproximar a ciência dos mesmos.

O terceiro texto (T3) consiste em um texto que apresentou a história de Rosalind Franklin e sua participação não repercutida nos estudos da estrutura de dupla hélice do DNA. O texto, por si só, apresentou dados relevantes para a promoção da natureza da ciência no seguinte fragmento: “... Atores fundamentais do episódio tiveram seu papel minimizado ou até mesmo esquecido, como o de Rosalind Franklin...”. Porém, em diversos momentos, o texto retirou fragmentos importantes como: "Há até quem diga que a pesquisadora foi passada para trás", "A imagem lhe foi mostrada por Wilkins sem consentimento de Franklin.".

O texto 4 não manteve dados referentes à natureza da ciência e, portanto, contribuiu para uma visão de ciência neutra ao retirar os dados referentes à pesquisa realizada (quadro 6). Conforme observado por Passeri et al., (2017) e Souza e Rocha (2014), também notou-se alterações da visão de natureza da ciência de um texto para o outro após a retirada de falas de pesquisadores. Tal mudança contribuiu em ambas as pesquisas, para uma visão negativa de ciência, de forma que as técnicas utilizadas e os procedimentos dos estudos não são contemplados pelo leitor. 
Considerou-se que T5 contribuiu para uma visão de natureza ciência, já que o texto apresenta técnicas que não foram bem sucedidas a partir da transfusão. Esta informação fica clara no trecho: "Em 1788, após tentativas fracassadas [...] ". Este fragmento explicitou que a ciência se consolida partir de tentativas e erros.

Assim como T5, T6 contribuiu para uma visão de natureza da ciência. O texto apresentou dados com base no Instituto Butantan de São Paulo, da revista britânica New Scientist e da Universidade de Newcastle. Além disso, no seguinte parágrafo “A equipe brasileira de cientistas, comandada por Irina Kerkis, ainda não demonstrou que os óvulos obtidos a partir de células masculinas sejam férteis para a viabilidade da descendência, mas já estão levando a experimentação bem-sucedida com os ratos para os embriões humanos." Observou-se que a ciência não possui dados prontos e que é preciso realizar testes e experimentos para comprovar a eficácia de determinada pesquisa.

Por último, T7 contribuiu parcialmente para uma visão de natureza da ciência. Apesar de o texto ter apresentado falas de pesquisador, ambientalista e ativista, o mesmo deixa de lado questões que deveriam ser apresentadas a fim de evidenciar ainda mais os debates existentes a respeito dos transgênicos, como a preocupação da população com a utilização deste tipo de alimento, expostas no seguinte fragmento retirado: "As preocupações manifestadas pelos participantes no ato de 8 de agosto --que o arroz representa riscos imprevisiveis para a saúde humana e o ambiente e que ele afinal servirá para dar lucro a grandes companhias agroquímica...”. Corroborando com esse resultado, Souza e Rocha (2014, p.65), durante a análise da natureza da ciência em um texto de ecologia, afirmam que este tipo de visão "inviabiliza ao aluno identificar que a ciência não está dissociada do contexto socioambiental", sendo necessário chamar atenção para os riscos que podem ser produzidos a partir de alimentos transgênicos.

\section{Linguagem}

Neste item, analisou-se a presença de possíveis erros conceituais, termos explicativos, metáforas e analogias. Vale lembrar que analogia é utilizada como uma forma de estabelecer um paralelo entre um determinado termo com outro semelhante a este a qual o leitor/público esteja mais acostumado, facilitando seu entendimento (SILVA et al., 2011). Já a metáfora consiste em uma comparação subentendida onde "conceitos científicos bem conhecidos são mapeados, pelo discurso comum, para outros domínios mais abstratos a fim de descrever sistemas complexos" (KINOUCHI et al., 2012, p.5).

O T1 não apresentou erros conceituais e metáforas, Contudo, tanto este texto quanto sua fonte original apresentaram uma analogia ao se referir às mitocôndrias, conforme pode ser observado: “... processo que acontece nas mitocôndrias, espécie de usina energética das 
células...". Nesta frase, as mitocôndrias são comparadas a uma usina energética, pelo fato de serem responsáveis pela respiração e pela produção de energia celular. A partir desta associação, acredita-se que o aluno consiga interpretar mais facilmente o conteúdo do texto.

O segundo texto (T2) apresentou uma analogia no seguinte fragmento: "A ideia é tirar a ciência do armário”, evidenciando que a ciência merece ser explorada e divulgada. Nos trechos "A máquina tira uma espécie de foto" e "O DNA das células é separado e fica misturado em um líquido verde" percebeu-se que tanto o texto didático quanto a fonte original buscaram simplificar e facilitar a compreensão do público a partir de palavras conhecidas do dia-a-dia do leitor, como 'máquina', 'foto' e 'líquido', tornando o conteúdo mais simplificado, ao invés de utilizar-se de termos científicos próprios para tais procedimentos. Assim como T1, este texto não apresentou erros conceituais e metáforas.

O T3 não se utilizou de recursos linguísticos como metáforas, analogias, termos explicativos, nem apresentou erros conceituais, sendo apenas considerado um texto informativo. Já T4, que continha poucos elementos de linguagem, apresentou apenas dois termos explicativos referentes à distrofia muscular e à sua proteína, distrofina. Vale lembrar que os termos explicativos foram observados em outras pesquisas, como na análise de Nascimento (2005). Segundo a autora, as explicações podem estar dispostas em pequenos fragmentos ou até em parágrafos inteiros, aproximando-se das explicações dispostas no discurso didático.

Em T5, foi observado apenas um termo explicativo sobre transfusões homólogas: “... realizando transfusões homólogas (entre animais da mesma espécie)...”. Além disso, notamos a presença de um erro conceitual, o qual foi ajustado para o texto didático (quadro 7). O erro consistiu na utilização da palavra 'coagular' ao invés da palavra 'aglutinar'. De acordo com o dicionário brasileiro, a palavra 'coagular' transmite a ideia de solidificação do sangue. Este termo geralmente é utilizado para explicar o processo de cicatrização de determinados ferimentos. Já a palavra 'aglutinar' está mais próxima da palavra 'aglomerar', 'unir', sendo mais aplicável para explicar a diferença e variabilidade dos sistemas sanguíneos. Os erros conceituais também foram encontrados na pesquisa de Souza e Rocha (2017a). Segundo estes autores, tais erros podem influenciar e prejudicar o aprendizado de diversos conceitos científicos.

O T6 apresentou apenas um termo explicativo referentes ao cromossomo Y: "a partir de células femininas, que carecem do cromossomo $Y$ - aquele que possui os genes que determinam o sexo masculino.". Os demais recursos linguísticos não foram observados. Por último, T7 apresentou metáforas, analogias e termos explicativos. A primeira foi encontrada no trecho "o arroz dourado seria um cavalo de Troia", no sentido de que o alimento conquistaria a população, mas também representaria em grandes benefícios para as empresas 
e corporações. Durante sua pesquisa com textos de genética, Nascimento e Martins (2005) observaram a presença de metáforas nas palavras 'receitas', 'instruções' e 'fabricar' para explicar a função dos genes. Segundo as autoras, este recurso serviu para facilitar a compreensão do aluno a partir da utilização de termos conhecidos no seu cotidiano. Já em relação à analogia, ela estava presente no fragmento "arroz dourado", que recebeu este nome devido à sua coloração amarelada devido à presença dos genes do milho e de bactérias que garantem a presença de betacaroteno em sua composição.

Ainda em relação a $\mathrm{T} 7$, foi possível observar uma breve explicação no fragmento " $A$ falta da vitamina A, nutriente vital, causa cegueira em 250 mil a 500 mil crianças por ano.", onde a cegueira é apresentada como uma consequência pela falta desta vitamina no organismo humano. Os termos explicativos garantem um traço didático ao texto por aproximarem os conceitos da realidade do aluno (SOUZA; ROCHA, 2017b).

\section{Grau de hibridez dos textos presentes no LD}

Nesta categoria, utilizou-se a definição de Souza (2017) para classificar o caráter dos textos apresentados no LD. De acordo com este autor, os textos podem ser considerados como: (i) textos híbridos (textos que foram modificados, sendo poucos semelhantes com suas fontes originais); (ii) semi-híbridos (que realizaram exclusões e, em menores quantidades, acréscimos, reordenações e substituições) e (iii) textos editados (que sofreram apenas exclusões de dados e não foram alterados em relação à fonte original).

Os textos T1, T3, T4 e T6 foram considerados textos editados, já que em suas reelaborações discursivas, os mesmos apresentaram apenas exclusões de dados e mantiveram todo o conteúdo presente no texto original. Já os textos T2, T5 e T7 foram considerados textos semi-híbridos por realizarem outras modificações nos textos, tais como acréscimos e substituições de palavras, além das eliminações (no caso de T5 e T6). Os textos híbridos não foram observados na análise, uma vez que os textos preservam muitas características das suas referências de origem.

\section{Considerações finais}

A DC representa um recurso importante capaz de aproximar o conhecimento científico do aluno. Quando apresentada juntamente com a genética nos LDs, a mesma é capaz de promover o interesse do aluno pelo tema, além de auxiliá-lo no desenvolvimento de aptidões como a leitura e a interpretação de textos.

Em relação à análise da categoria de reelaboração discursiva, notou-se que as eliminações foram os elementos mais observados na maioria dos textos, com exceção de T2. 
Os elementos de substituições e acréscimos foram observados em menores quantidades e as reordenações de informações não foram observadas.

$\mathrm{Na}$ categoria de natureza da ciência, identificou-se que a maioria dos textos contribuiu/contribuiu parcialmente para uma visão de ciência não neutra, mostrando o processo de construção do conhecimento científico, opiniões e falas de pesquisadores que contribuíram para os estudos abordados. Esta análise, por sua vez, nos permite inferir que, ao manter este tipo de visão no LD, o autor colaborou para que o estudante possa entender que a ciência necessita de pesquisas e estudos e que ela não é realizada de forma instantânea, portanto, sendo passível de erros.

Em relação à linguagem, notou-se que quase todos os textos utilizaram recursos linguísticos (metáforas, analogias e/ou termos explicativos). Este fato retrata a intenção dos autores (tanto do texto original quanto do texto presente no LD) de tornar a informação mais clara e compreensível para o público leitor na tentativa de aproximá-los do conhecimento científico, assim como visa a DC.

Em relação ao grau de hibridez dos textos presentes no LD, a maioria foi considerada como texto editado, onde apesar das grandes exclusões, os mesmos preservaram grande parte do texto original. A partir desta informação pode-se dizer que estes textos não foram significativamente modificados de sua fonte original e que, possivelmente, o autor do LD buscou trazer apenas o que considerou ser essencial para ser tratado juntamente ao conteúdo presente no capítulo e que tais eliminações foram realizadas a fim de reduzir o tamanho dos textos.

A partir da pesquisa realizada conclui-se que os sete textos representam recursos importantes para serem inseridos no ensino, não apenas pela relevância de suas temáticas, mas devido a capacidade de gerar discussões e oferecer a possibilidade do estudante refletir sobre como a ciência tem sido atrelada à tecnologia, à questões éticas, sociais, políticas e econômicas. Desta forma, recomenda-se também que os docentes ajam como mediadores neste processo, uma vez que o mesmo pode auxiliar na condução dos estudos e no processo de ensino-aprendizagem destes jovens.

\section{Referências}

BARDIN, L. Análise de conteúdo. 3ª ed. Lisboa: Edições 70, 1977.

BRASIL. Secretaria de Educação Fundamental. Parâmetros Curriculares Nacionais : Ciências Naturais / Secretaria de Educação Fundamental.Brasília : MEC / SEF, p.19-122, 1998. 
BRASIL. Ministério da Educação. PNLD 2018: guia de livros didáticos - ensino médio / Ministério da Educação - Secretária de Educação Básica - Fundo Nacional de Desenvolvimento da Educação. Brasília, DF: 2017. Disponível em: http://www.fnde.gov.br/pnld-2018/.

BUENO, W. C. Comunicação Científica e Divulgação Científica: aproximações e rupturas conceituais. Informação \& Informação, v. 15, n. esp, p. 1-12, 2010.

CAREGNATTO, R. C. A; MUTTI, R. Pesquisa qualitativa: análise de discurso versus análise de conteúdo. Texto \& Contexto: Enfermagem, v. 15, n. 4, p.679-684, 2006.

DIAS, G.R; SILVA, J. M; BENTO, J. I.M; CATANHEDE, S. C.S; CATANHEDE, L. B. Textos de divulgação científica: análise e caracterização para utilização no ensino de matemática. Revista Eletrônica de Educação Matemática, v. 11, n. 1, p. 84-98, 2016.

FERRARI, P. C; ANGOTTI, J. A; CRUZ, F. F. S. A divulgação científica na educação escolar: discutindo um exemplo. In: ENCONTRO NACIONAL DE PESQUISA EM EDUCAÇÃO EM CIÊNCIAS, 5., 2005, Bauru. Atas..., Bauru, 5., 2005.

FERREIRA, L. N. A.; QUEIROZ, S. L. Textos de divulgação científica no ensino de ciências: uma revisão. Alexandria: Revista de Educação em Ciência e Tecnologia, v.5, n.1, p.3-31, 2012.

FIOREZE, J. Z; DELIZOICOV, N. C. Livros didáticos de Biologia e a história da Ciência. Roteiro, v. 40, n. 1, p.101-126, 2015.

GIL, A. C. Como elaborar projetos de pesquisa. 4ªed. São Paulo: Atlas, 2002.

GOLDBACH, T; EL-HANI, C. Entre Receitas, Programas e Códigos: Metáforas e Idéias Sobre Genes na Divulgação Científica e no Contexto Escolar. Alexandria: Revista de Educação em Ciência e Tecnologia , v. 1, n. 1, p.153-189, 2008.

GOMES, I. Dos laboratórios aos jornais: Um estudo sobre o jornalismo científico. Dissertação de mestrado do Programa de Pós-graduação em Letras e Lingüística. Centro de Artes e Comunicação, UFPE, Recife, 1995.

KEMPER, A; ZIMMERMANN, E; GASTAL, M. L. Textos populares de divulgação científica como ferramentas didático pedagógica: o caso da evolução biológica. Revista Brasileira de Pesquisa em Educação em Ciências, v. 10, n. 3, p.25-50, 2010.

KINOUCHI, O; KINOUCHI, J.M; MANDRÁ, A. A. Metáforas científicas no discurso jornalístico. Revista Brasileira de Ensino de Física, v. 34, n. 4, p. 1-12, 2012.

LOUREIRO, J. M. M. Museu de ciência, divulgação científica e hegemonia. Ci. Inf., Brasília, v. 32, n. 1, p. 88-95, 2003.

MARTINS, I; CASSAB, M.; ROCHA, M. B. Análise do processo de re-elaboração discursiva de um texto de divulgação científica para um texto didático. Revista Brasileira de Pesquisa em Educação em Ciências, v.1, n.3, p.1-9, 2001. 
MASCARENHAS, M. J. O; SILVA; V. C; MARTINS, P. R. P; FRAGA, E. C; BARROS, M. C. Estratégias metodológicas para o ensino de genética em escola pública. Pesquisa em foco, v. 21, n. 2, p. 05-24, 2016.

MOREIRA, I. C; MASSARANI, L. Aspectos históricos da divulgação científica no Brasil. In: MASSARANI, L; MOREIRA, I. C; BRITO, F. (Orgs). Ciência e público: caminhos da divulgação científica no Brasil. Rio de Janeiro: Casa da Ciência, 2002. p .43- 64.

MOURA, J; DEUS, M. S. M; GONÇALVES, N. M. N; PERON, A. P. Biologia/Genética: O ensino de biologia, com enfoque a genética, das escolas públicas no Brasil - breve relato e reflexão. Semina: Ciências Biológicas e da Saúde, Londrina, v. 34, n. 2, p. 167-174, 2013.

NASCIMENTO, T. G. O discurso da divulgação científica no livro didático de ciências: características, adaptações e funções de um texto sobre clonagem. Revista Brasileira de Pesquisa em Educação em Ciências, v. 5, n. 2, p.15-28, 2005.

NASCIMENTO, T. G; MARTINS, I. O texto de genética no livro didático de ciências: uma análise retórica crítica. Investigações em Ensino de Ciências, v. 10, n. 2, p. 255-278, 2005.

PASSERI, M.G; AIRES, R.M; ROCHA, M. B. Reelaboração discursiva de um texto de divulgação científica sobre crise hídrica em um livro didático de Ciências. Ensino, Saúde e Ambiente, v. 10, n.1, p. 142-162, 2017.

PUIATI, L. L; BOROWSKY, H. G; TERRAZZAN, E. A. O texto de divulgação científica como recurso para o ensino de Ciências na Educação Básica: um levantamento das produções do ENPEC. In: VI ENCONTRO NACIONAL DE PESQUISA EM EDUCAÇÃO EM CIÊNCIAS, 6., 2007, Florianópolis. Atas..., Florianópolis/ SC, 2007.

SÁ-SILVA, J. R; ALMEIDA, C. D; GUINDANI, J. F. Pesquisa documental: pistas teóricas e metodológicas. Revista Brasileira de História \& Ciências Sociais, v.1, n.1, p.1-15, 2009.

SILVA, H. C. O que é divulgação científica? Ciência \& Ensino, v.1, n.1, p. 53-59, 2006.

SILVA, L.L; PIMENTEL, N.L; TERRAZZAN, E. As analogias na revista de divulgação científica ciência hoje das crianças. Ciência \& Educação, v. 17, n. 1, p. 163-181, 2011.

SOUZA, P. H. R. Análise dos textos de divulgação científica referentes à biologia animal em livros didáticos de biologia para o ensino médio. Tese de doutorado. Programa de PósGraduação em Ciência, Tecnologia e Educação, Centro Federal de Educação Tecnológica Celso Suckow da Fonseca (CEFET/RJ), p.1-223, 2017.

SOUZA, P. H.R; ROCHA, M. B. Análise do processo de Reelaboração Discursiva na incorporação de um texto de Divulgação Científica no livro de Ciências. Revista Brasileira de Ensino de Ciência e Tecnologia, v. 7, n. 1, p.53-69, 2014.

SOUZA, P. H. R; ROCHA, M. B. Caracterização dos textos de divulgação científica inseridos em livros didáticos de biologia. Investigações em Ensino de Ciências, v. 20, n. 2, p. 126-137, 2015.

SOUZA, P. H. R; ROCHA, M. B. Análise da linguagem de textos de divulgação científica em livros didáticos: contribuições para o ensino de biologia. Ciência \& Educação, v. 23, n. 2, p. 321-340, 2017a. 
SOUZA, P. H. R; ROCHA, M. B. A linguagem e o discurso de textos de divulgação científica inseridos em livros didáticos. Enseñanza de las ciencias p. 4659-4664, 2017 b.

TARGINO, M. G. Divulgação científica e discurso. Comunicação \& Inovação, v.8, n.15, p. 19-28, 2007.

TEIXEIRA, I. M; SILVA, E. P. História da eugenia e ensino de genética. História da Ciência e Ensino, v. 15, p. 63-80, 2017.

TEMP, D. S; BARTHOLOMEI-SANTOS, M. L. Genética e suas aplicações: identificando o conhecimento presente entre concluintes do ensino médio. Ciência e Natura, v. 36, n. 2, p. $358-372,2014$.

XAVIER, M. C. F.; FREIRE, A.S; MORAES, M. O. A nova (moderna) biologia e a genética nos livros didáticos de biologia no ensino médio. Ciência \& Educação, v. 12, n. 3, p. 275$289,2006$.

ZAMBONI, L. M. S. Heterogeneidade e subjetividade no discurso da divulgação científica. Tese (Doutorado) - Instituto de Estudos da Linguagem, Universidade Estadual de Campinas p.1-211, 1997.

\section{SOBRE OS AUTORES}

BRUNA SARPA MICELI. Iniciou mestrado em Ciência, Tecnologia e Educação no CEFET-RJ em maio de 2017. É especialista em Ensino de Ciências na Universidade do Estado do Rio de Janeiro (UERJ). Graduada em Ciências Biológicas (licenciatura) na Universidade Veiga de Almeida no ano de 2015.

MARCELO BORGES ROCHA. Possui graduação em Ciências Biológicas pela Universidade Federal do Rio de Janeiro (2000), Mestrado em Educação em Ciências e Saúde Núcleo de Tecnologia Educacional para a Saúde pela Universidade Federal do Rio de Janeiro (2003) e Doutorado em Ciências Biológicas (Zoologia) pela Universidade Federal do Rio de Janeiro (2011). Possui Pós-doutorado em Administração Pública pela EBAPE na Fundação Getúlio Vargas.Atuou como Professor Assistente do Centro Universitário Augusto Motta e da Universidade Estácio de Sá. Tem experiência na área de Educação, Biologia Marinha e Zoologia, atuando principalmente nos seguintes temas: divulgação científica, taxonomia, biologia marinha e biologia molecular. Leciona disciplinas relacionadas à Bioquímica,Biologia Marinha, Pesquisa e Prática na área de Biologia, Ecologia e Microbiologia. Atualmente atuo como professor no Ensino Superior e no Programa de Pós Graduação em Ciência, Tecnologia e Educação do Centro Federal de Educação Tecnológica Celso Suckow da Fonseca (CEFET/RJ). Além disso, sou chefe da Divisão de Editoração, responsável pela Revista Tecnologia e Cultura e coordeno o Laboratório de Divulgação Cientifica e Ensino de Ciências (LABDEC). Atuo como avaliador junto ao INEP/MEC para credenciamento e recredenciamento de cursos superiores no Brasil.

Recebido: 02 de julho de 2018.

Revisado: 22 de dezembro de 2018.

Aceito: 22 de fevereiro de 2019. 